\title{
Physiological analysis of leaf senescence of two rice cultivars with different yield potential
}

\author{
Antelmo Ralph Falqueto(1), Daniela Cassol(2), Ariano Martins de Magalhães Júnior ${ }^{(3)}$, \\ Antônio Costa de Oliveira ${ }^{(4)}$ and Marcos Antonio Bacarin ${ }^{(2)}$
}

\begin{abstract}
(1)Universidade Federal do Espírito Santo, Departamento de Ciências da Saúde, Biológicas e Agrárias, Rodovia BR 101 Norte, Km 60, Bairro Litorâneo, CEP 29932-540 São Mateus, ES, Brazil. E-mail: antelmofalqueto@yahoo.com.br (2)Universidade Federal de Pelotas (UFPel), Departamento de Botânica, Instituto de Biologia, CEP 96010-900 Pelotas, RS, Brazil. E-mail: danicassol@gmail.com, bacarin@ufpel.edu.br ${ }^{(3)}$ Embrapa Clima Temperado, Caixa Postal 403, CEP 96001-970 Pelotas, RS, Brazil. E-mail: ariano@cpact.embrapa.br (4)UFPel, Faculdade de Agronomia Eliseu Maciel, Departamento de Fitotecnia. E-mail: acosta@ufpel.edu.br
\end{abstract}

\begin{abstract}
The objective of this work was to evaluate the physiological changes that occur in different leaves during the early and late grain-filling stages of two rice genotypes (Oryza sativa subsp. indica, BRS Pelota cultivar, and $O$. sativa subsp. japonica, BRS Firmeza cultivar), which present differences in grain yield potential. The plants were cultivated in greenhouse. Pigment content, chlorophyll fluorescence, electron transport and oxygen evolution rate were determined in the grain-filling stage, from the first to the forth leaf (top to bottom). Pigment content, photochemical efficiency of photosystem II and electron transport decreased significantly according to the position of leaves in 'BRS Pelota'. The BRS Firmeza cultivar shows higher pigment content and higher activity of the photosynthetic apparatus in comparison to 'BRS Pelota' during the grain-filling stage.
\end{abstract}

Index terms: Oryza sativa, oxygen evolution rate, photochemical quenching, photosystem II, photochemicol efficiency, stay green.

\section{Análise fisiológica da senescência foliar de duas cultivares de arroz com diferentes potenciais de produtividade}

\begin{abstract}
Resumo-O objetivo deste trabalho foi avaliar as mudanças fisiológicas que ocorrem em diferentes folhas durante o início e o final do estádio de enchimento de grãos em dois genótipos de arroz (Oryza sativa subsp. indica cultivar BRS Pelota e $O$. sativa subsp. japonica cultivar BRS Firmeza) que apresentam diferenças no potencial de produção de grãos. As plantas foram cultivadas em casa de vegetação. Os teores de pigmentos, a fluorescência da clorofila e a taxa de liberação de oxigênio foram determinados no estádio de enchimento de grão da primeira à quarta folha (do topo à base). O teor de pigmentos, a eficiência fotoquímica do fotossistema II e o transporte de elétrons decresceram significativamente de acordo com a posição das folhas na cultivar BRS Pelota. A cultivar BRS Firmeza apresentou maior teor de pigmentos e maior atividade do aparato fotossintético em comparação à 'BRS Pelota' durante o estádio de enchimento de grão.
\end{abstract}

Termos para indexação: Oryza sativa, taxa de evolução de oxigênio, extinção fotoquímica, fotossistema II, eficiência fotoquímica, senescência retardada.

\section{Introduction}

Senescence is a normal event in the life cycle of plants (Borrás et al., 2003). It is a sequence of complex degenerative processes that are initiated at full maturity and may ultimately lead to leaf death (Camp et al., 1982; Thomas et al., 2003; Tang et al., 2005). The most remarkable events in leaf senescence are the loss of chlorophyll and the disassembly of the photosynthetic apparatus, which result in decreases in the photosynthetic energy conversion capacity and efficiency. Also, there is a concurrent decline in chain electron transport for those components remaining in the leaf (Adams et al., 1990; Weng et al., 2005; Zhang et al., 2006). The decrease in electron transport along photosystem II may be due to an inactivation of the oxygen evolution system or of the photosystem II reaction center complex, as well as to the inhibition of energy transfer from carotenoids to chlorophyll (Lu et al., 2002). In addition, senescence also affects the composition of the antenna system of photosynthesis. According to Kura-Hotta et al. (1987), chlorophyll $a$ disappears more 
rapidly than chlorophyll $b$ during senescence, resulting in a decrease in the chlorophyll $a / b$ ratio.

Many studies related to the senescence of rice leaves have been reported (Biswas \& Choudruri, 1980; Kura-Hotta et al., 1987; Hidema et al., 1991; Yamazaki et al., 1999; Tang et al., 2005; Weng et al., 2005). Historically, researches on biochemical changes that occur during leaf senescence have focused on loss of photosynthetic pigments, degradation of protein, and reabsorption of mineral nutrients (Zhang et al., 2006). Reductions in photosystem II (PSII) activity, expressed through the analyses of chlorophyll fluorescence and electron transport chain, have recently been examined during the senescence of leaves in different cultivars of super-high-yielding hybrid rice (Jiao et al., 2003; Weng et al., 2005). However, most of these investigations have focused on senescence processes at the single-leaf level.

Chlorophyll $a$ fluorescence has been shown to be a noninvasive and reliable method to assess the changes in PSII function under different environmental conditions (Krause \& Weis, 1991). The use of this method to assess PSII photochemistry, during leaf senescence in cultivars with differences in grain yield potential, is important because it gives new insights about the fundamental processes of energy absorption and excess excitation energy use and dissipation by PSII in cereal crop plants during senescence. Moreover, leaf senescence pattern is commonly variable, and differences in canopy depth and leaf senescence should exist among cultivars, for they might contribute to the differences observed in grain yield.

Tropical Oryza sativa subsp. japonica rice cultivar BRS Firmeza presents stay-green phenotype and has shown later senescence than $O$. sativa subsp. indica rice cv. BRS Pelota. The stay-green trait may result from a delay in the onset of leaf senescence, from a reduced rate of senescence, or from the inhibition of one of the partial processes involved in chlorophyll breakdown (Thomas \& Howarth, 2000; Luquez \& Guiamét, 2001). On the theoretical basis, the stay-green trait may cause, different impacts on grain yield as a result of a delay in the onset of leaf senescence or of a lower photosynthetic decline rate, which extends the assimilatory capacity of the canopy, contributing to higher grain formation (Luquez \& Guiamét, 2001; Rampino et al., 2006).

The objective of this work was to evaluate the physiological changes that occur in different leaves during the early and late grain-filling stages of two rice genotypes (O. sativa subsp. indica BRS Pelota cultivar - high grain production; and O. sativa subsp. japonica BRS Firmeza cultivar - low grain production).

\section{Materials and Methods}

Plants of rice (O. sativa L.) cultivars BRS Firmeza (O. sativa subsp. japonica) and BRS Pelota (O. sativa subsp. indica) were grown to the ripening stage (about 4-5 months) in a greenhouse under natural light conditions. The experiment was carried out in summer, from november 2007 to february 2009 at Pelotas, RS, Brazil. These cultivars were chosen because of their differences in grain-yield potential (7.5 and $10 \mathrm{Mg} \mathrm{ha}^{-1}$ for 'BRS Firmeza' and 'BRS Pelota', respectively). 'BRS Firmeza' presents stay-green phenotype, characterized by an extended green leaf color period, which is longer than the one for BRS Pelota cultivar.

The experimental design was completely randomized with two rice cultivars and two grain-filling stages, with ten replicates for each rice cultivar. Each replicate was composed of one plastic pot $(12 \mathrm{~L})$ filled with soil fertilized according to Santos et al. (2006). Twenty-five seeds were sown in each pot. In order to obtain uniform plants, the seedlings of each pot were thinned from 25 to 5 per pot after the appearance of the second leaf. Thereafter, a water depth of 3 to $5 \mathrm{~cm}$ was maintained until maturity. Leaf samples were collected from the plants during the early (100 days) and late (115 days) grain-filling stages in both cultivars. The changes in photosynthetic pigment content, chlorophyll fluorescence parameters and oxygen evolution rate in the flag leaf (further referred to as $1^{\text {st }}$ leaf) and the second, third and fourth leaves were considered as a senescence index.

Chlorophyll and carotenoids were extracted with $80 \%$ acetone (Arnon, 1949) and determined using a spectrophotometer (Ultrapec 2100 pro, Biochrom Ltd., England) according to Lichtenthaler (1987). Chlorophyll $a$ fluorescence was measured using a fluorescence monitoring system (FMS2, Hansatech, England) after the leaves were dark-adapted for $20 \mathrm{~min}$. The minimal fluorescence level $\left(\mathrm{F}_{0}\right)$ with all PSII reaction centers opened was determined by measuring modulated light, which was enough to avoid any significant variation in fluorescence. The maximal 
fluorescence level $\left(\mathrm{F}_{\mathrm{M}}\right)$ with all PSII reaction centers closed was determined by applying a saturating pulse on dark-adapted leaves. Then, the leaf was continuously illuminated with a white actinic light. The steady-state value of fluorescence $\left(F_{s}\right)$ was reached and a second saturating pulse was applied to determine the maximal fluorescence level in the light-adapted state $\left(\mathrm{F}_{\mathrm{M}}{ }^{\prime}\right)$. The actinic light was then removed and the minimal fluorescence level in the light-adapted state $\left(\mathrm{F}_{0}{ }^{\prime}\right)$ was determined by illuminating the leaf with far-red light.

With the measurement of fluorescence, the following parameters were calculated: maximal efficiency of PSII photochemistry in dark-adapted state, $\mathrm{F}_{\mathrm{V}} / \mathrm{F}_{\mathrm{M}}$; photochemical quenching coefficient, $\mathrm{qP}=\left(\mathrm{F}_{\mathrm{M}}{ }^{\prime}-\mathrm{F}_{\mathrm{s}}\right) /\left(\mathrm{F}_{\mathrm{M}^{\prime}}{ }^{\prime}-\mathrm{F}_{0}{ }^{\prime}\right)$; effective efficiency of PSII photochemistry, $\mathrm{F}_{\mathrm{V}^{\prime}}-\mathrm{F}_{\mathrm{M}}{ }^{\prime}$; actual quantum yield of PSII electron transport in light-adapted state, $\varphi_{\text {PSII }}=\left(F_{M}^{\prime}-F_{s}\right) / F_{M}{ }^{\prime}$ (Genty et al., 1989). The electron transfer rate through photosystem II (ETR) was calculated from the fluorescence data using the formula from Krall $\&$ Edwards (1992): $\mathrm{ETR}=\Phi_{\mathrm{PSII}} \times 0.85 \times 0.5 \times \mathrm{PPFD}$, where 0.85 represents the estimated proportion of incident photons absorbed by the leaf (usually $80 \%$ ), 0.5 indicates an estimated value for the distribution proportion of energy in PSII (usually $50 \%$ in $\mathrm{C}_{3}$ plants), and PPFD indicates the photosynthetic photon flux density.

The photosynthetic rate (maximum oxygen evolution rate) was determined using a gas-phase oxygen electrode (Leaf Lab, Hansatech, England). A piece of about $3 \mathrm{~cm}^{2}$ was cut from the center of the leaf blade. The determinations of oxygen evolution rate were conducted under the following conditions: air temperature of $30^{\circ} \mathrm{C}$ and $2,000 \mu \mathrm{mol} \mathrm{m}^{-2} \mathrm{~s}^{-1}$ irradiation. The $\mathrm{CO}_{2}$ was supplied as a $1 \mathrm{~mol} \mathrm{~L}^{-1}$ solution of sodium bicarbonate. The photosynthetic rate, expressed in $\mu \mathrm{mol}\left(\mathrm{O}_{2}\right) \mathrm{m}^{-2} \mathrm{~s}^{-1}$, was calculated when the oxygen evolution curve became stable. The effect of different parameters was analyzed by ANOVA using a SPSS 11.5 statistical package (SPSS, USA).

\section{Results and Discussion}

Total chlorophyll content, chlorophyll $a / b$ ratio and total carotenoids in leaves decreased according to the position of leaves in 'BRS Pelota' in both stages (Table 1). In 'BRS Firmeza', however, these values did not decrease markedly. These results indicate that the senescence of rice leaves may not be a simple function of leaf age, as indicated by Biswas et al. (1980), but may primarily be under genetic control (Okada, 1998; Yamazaki et al., 1999). 'BRS Firmeza' shows stay-green phenotype (Magalhães Júnior et al., 2003), characterized by an extended leaf green color period, which can arise from delays in the beginning of senescence and in senescence progress, as previously indicated by Rampino et al. (2006).

The loss of chlorophyll and the concurrent yellowing of the leaves are convenient and distinctive indicators of leaf senescence. That characteristic phenotype can be uncoupled from physiological leaf senescence. The well-known phenomenon of leaf senescence is the loss of chlorophyll content. According to Wiedemuth et al. (2005), chlorophyll content is a widely used parameter for measuring the degradation of the photosynthetic apparatus in leaves during senescence. The changes in chlorophyll $a / b$ ratio indicate that there are differential changes in the photosynthetic pigment stoichiometry during late senescence between $O$. sativa subsp. indica BRS Pelota cultivar and $O$. sativa subsp. japonica BRS Firmeza cultivar. It is assumed that the conversion of chlorophyll $b$ to $a$ represents a critical factor for changes in chlorophyll $a / b$ ratio (Zhang et al., 2006). Gossauer \& Engel (1996) stated that the conversion of chlorophyll $b$ to $a$ should precede chlorophyll degradation in higher plants. Thus, the differences in chlorophyll $a / b$ ratio observed between 'BRS Pelota' and 'BRS Firmeza' should reflect genetic differences

Table 1. Chlorophyll content ( $\mu \mathrm{mol} \mathrm{\textrm {g } ^ { - 1 }}$ of fresh matter), chlorophyll $a / b$ ratio and total carotenoids ( $\mu \mathrm{mol} \mathrm{g} \mathrm{g}^{-1}$ of fresh matter) from the first to the forth leaf of BRS Pelota and BRS Firmeza rice cultivars at early (GF1) and late (GF2) grain-filling stages ${ }^{(1)}$.

\begin{tabular}{|c|c|c|c|c|c|}
\hline \multirow[t]{2}{*}{ Parameter } & \multirow{2}{*}{ Leaf position } & \multicolumn{2}{|c|}{ BRS Pelota } & \multicolumn{2}{|c|}{ BRS Firmeza } \\
\hline & & $\mathrm{GF}_{1}$ & $\mathrm{GF}_{2}$ & $\mathrm{GF}_{1}$ & $\mathrm{GF}_{2}$ \\
\hline \multirow{4}{*}{ Total chlorophyll } & $1^{\text {st }}$ & $3.29 \mathrm{a}$ & $2.16 \mathrm{a}$ & $3.13 a$ & $1.76 \mathrm{a}$ \\
\hline & $2^{\text {nd }}$ & $2.18 b$ & $1.96 \mathrm{a}$ & $2.60 \mathrm{ab}$ & $1.49 \mathrm{a}$ \\
\hline & $3^{\text {rd }}$ & $1.91 \mathrm{~b}$ & $0.54 \mathrm{~b}$ & $2.59 \mathrm{ab}$ & $1.05 \mathrm{a}$ \\
\hline & $4^{\text {th }}$ & $0.74 b$ & $-(2)$ & $1.99 \mathrm{~b}$ & $1.23 \mathrm{a}$ \\
\hline \multirow{4}{*}{ Chlorophyll $a / b$ ratio } & $1^{\text {st }}$ & $3.54 \mathrm{a}$ & $2.62 \mathrm{a}$ & $3.71 \mathrm{a}$ & $3.04 \mathrm{a}$ \\
\hline & $2^{\text {nd }}$ & $3.12 \mathrm{a}$ & $2.60 \mathrm{a}$ & $3.55 \mathrm{a}$ & $3.29 \mathrm{a}$ \\
\hline & $3^{\text {rd }}$ & $3.35 \mathrm{a}$ & $1.86 \mathrm{~b}$ & $3.72 \mathrm{a}$ & $2.83 a$ \\
\hline & $4^{\text {th }}$ & $3.08 \mathrm{a}$ & - & $3.52 \mathrm{a}$ & $2.73 \mathrm{a}$ \\
\hline \multirow{4}{*}{ Total carotenoids } & $1^{\text {st }}$ & $0.62 \mathrm{a}$ & $0.50 \mathrm{a}$ & $0.64 a$ & $0.40 \mathrm{a}$ \\
\hline & $2^{\text {nd }}$ & $0.52 b$ & $0.54 \mathrm{a}$ & $0.55 \mathrm{a}$ & $0.43 \mathrm{a}$ \\
\hline & $3^{\text {rd }}$ & $0.48 b$ & $0.24 \mathrm{~b}$ & $0.55 \mathrm{a}$ & $0.34 \mathrm{a}$ \\
\hline & $4^{\text {th }}$ & $0.23 \mathrm{c}$ & - & $0.43 \mathrm{a}$ & $0.32 \mathrm{a}$ \\
\hline
\end{tabular}

${ }^{(1)}$ Means $(n=5)$ followed by equal letters in the parameter do not differ by Tukey's test, at $5 \%$ probability. ${ }^{(2)}$ Completely senescent leaves. 
associated to the conversion capacity of each rice cultivar, which results from the presence of stay-green genes in the BRS Firmeza cultivar.

The decline of photosynthetic pigment content was consistent with a loss of maximal photochemical efficiency of PSII $\left(\mathrm{F}_{\mathrm{V}} / \mathrm{F}_{\mathrm{M}}\right)$ in O. sativa subsp. indica BRS Pelota cultivar, in both stages (Table 2). The $\mathrm{F}_{\mathrm{V}} / \mathrm{F}_{\mathrm{M}}$ values were similar between the $1^{\text {st }}$ (flag leaf) and $2^{\text {nd }}$ leaves during the early and late grain-filling stages, but they decreased in the $3^{\text {rd }}$ and $4^{\text {th }}$ leaves. These results were also verified in the $\mathrm{F}_{\mathrm{v}} / \mathrm{F}_{0}$ ratio, which can be used as a parameter indicator of maximum efficiency of the PSII photochemical process as well

Table 2. Maximal photochemical efficiency of PSII $\left(\mathrm{F}_{\mathrm{V}} / \mathrm{F}_{\mathrm{M}}\right)$, maximum quantum yield ratio of photochemical and concurrent non-photochemical processes in PSII $\left(\mathrm{F}_{\mathrm{V}} / \mathrm{F}_{0}\right)$, effective photochemical efficiency of PSII $\left(\mathrm{F}_{\mathrm{V}}{ }^{\prime} / \mathrm{F}_{\mathrm{M}}{ }^{\prime}\right)$, photochemical extinction coefficient $(\mathrm{qP})$, actual photochemical efficiency of PSII $\left(\varphi_{\text {PSII }}\right)$, electron transport through PSII (ETR, $\mu$ mol electrons $\mathrm{m}^{-2} \mathrm{~s}^{-1}$ ) and oxygen evolution rate (OER, $\mu \mathrm{mol} \mathrm{O}_{2} \mathrm{~m}^{-2} \mathrm{~s}^{-1}$ ) from the first to the forth leaf of BRS Pelota and BRS Firmeza rice cultivars at early $\left(\mathrm{GF}_{1}\right)$ and late $\left(\mathrm{GF}_{2}\right)$ grain-filling stages ${ }^{(1)}$.

\begin{tabular}{|c|c|c|c|c|c|}
\hline \multirow[t]{2}{*}{ Parameter } & \multirow{2}{*}{$\begin{array}{c}\text { Leaf } \\
\text { position }\end{array}$} & \multicolumn{2}{|c|}{ BRS Pelota } & \multicolumn{2}{|c|}{ BRS Firmeza } \\
\hline & & $\mathrm{GF}_{1}$ & $\mathrm{GF}_{2}$ & $\mathrm{GF}_{1}$ & $\mathrm{GF}_{2}$ \\
\hline \multirow{4}{*}{$\mathrm{F}_{\mathrm{V}} / \mathrm{F}_{\mathrm{M}}$} & $1^{\mathrm{st}}$ & $0.838 \mathrm{a}$ & $0.835 \mathrm{a}$ & $0.847 \mathrm{a}$ & $0.838 \mathrm{a}$ \\
\hline & $2^{\text {nd }}$ & $0.836 \mathrm{a}$ & $0.797 \mathrm{a}$ & $0.847 \mathrm{a}$ & $0.831 \mathrm{a}$ \\
\hline & $3^{\text {rd }}$ & $0.800 \mathrm{ab}$ & $0.678 b$ & $0.829 \mathrm{a}$ & $0.817 \mathrm{a}$ \\
\hline & $4^{\text {th }}$ & $0.749 \mathrm{~b}$ & $-(2)$ & $0.825 \mathrm{a}$ & $0.828 \mathrm{a}$ \\
\hline \multirow{4}{*}{$\mathrm{F}_{\mathrm{V}} / \mathrm{F}_{0}$} & $1^{\text {st }}$ & $4.94 a$ & $5.07 \mathrm{a}$ & $5.56 \mathrm{a}$ & $5.21 \mathrm{a}$ \\
\hline & $2^{\text {nd }}$ & $5.19 \mathrm{a}$ & $4.26 \mathrm{a}$ & $5.27 \mathrm{a}$ & $5.00 \mathrm{a}$ \\
\hline & $3^{\text {rd }}$ & $3.76 \mathrm{~b}$ & $2.20 \mathrm{~b}$ & $4.84 \mathrm{a}$ & $4.53 \mathrm{a}$ \\
\hline & $4^{\text {th }}$ & $3.48 \mathrm{~b}$ & $-(2)$ & $4.48 \mathrm{a}$ & $4.83 \mathrm{a}$ \\
\hline \multirow{4}{*}{ 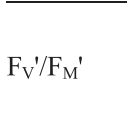 } & $1^{\text {st }}$ & $0.714 a$ & $0.450 \mathrm{a}$ & $0.664 a$ & $0.602 a$ \\
\hline & $2^{\text {nd }}$ & $0.698 \mathrm{a}$ & $0.422 \mathrm{a}$ & $0.685 \mathrm{a}$ & $0.495 b$ \\
\hline & $3^{\text {rd }}$ & $0.601 \mathrm{a}$ & $0.326 \mathrm{a}$ & $0.709 a$ & $0.538 \mathrm{ab}$ \\
\hline & $4^{\text {th }}$ & $0.635 \mathrm{a}$ & - & $0.684 \mathrm{a}$ & $0.477 \mathrm{~b}$ \\
\hline \multirow{4}{*}{$\mathrm{qP}$} & $1^{\text {st }}$ & $0.950 \mathrm{a}$ & $0.931 \mathrm{a}$ & $0.957 \mathrm{a}$ & $0.805 a$ \\
\hline & $2^{\text {nd }}$ & $0.954 \mathrm{a}$ & $0.853 \mathrm{a}$ & $0.894 \mathrm{a}$ & $0.817 \mathrm{a}$ \\
\hline & $3^{\text {rd }}$ & $0.958 \mathrm{a}$ & $0.845 \mathrm{a}$ & $0.935 \mathrm{a}$ & $0.899 \mathrm{a}$ \\
\hline & $4^{\text {th }}$ & $0.930 \mathrm{a}$ & - & $0.945 \mathrm{a}$ & $0.880 \mathrm{a}$ \\
\hline \multirow{4}{*}{$\varphi_{\text {PSII }}$} & $1^{\text {st }}$ & $0.657 \mathrm{a}$ & $0.431 \mathrm{a}$ & $0.646 a$ & $0.469 \mathrm{a}$ \\
\hline & $2^{\text {nd }}$ & $0.665 a$ & $0.358 \mathrm{a}$ & $0.616 a$ & $0.509 \mathrm{a}$ \\
\hline & $3^{\text {rd }}$ & $0.616 \mathrm{a}$ & $0.333 \mathrm{a}$ & $0.649 \mathrm{a}$ & $0.469 \mathrm{a}$ \\
\hline & $4^{\text {th }}$ & $0.596 \mathrm{a}$ & - & $0.647 \mathrm{a}$ & $0.519 \mathrm{a}$ \\
\hline \multirow{4}{*}{ ETR } & $1^{\text {st }}$ & $120.4 a$ & $68.2 \mathrm{a}$ & $161.4 \mathrm{a}$ & $63.2 \mathrm{a}$ \\
\hline & $2^{\text {nd }}$ & $116.9 \mathrm{a}$ & $52.8 \mathrm{a}$ & $121.4 \mathrm{a}$ & $66.1 \mathrm{a}$ \\
\hline & $3^{\text {rd }}$ & $79.4 b$ & $35.8 \mathrm{~b}$ & $53.8 \mathrm{~b}$ & $44.5 b$ \\
\hline & $4^{\text {th }}$ & $64.1 \mathrm{~b}$ & - & $70.1 \mathrm{~b}$ & $38.9 \mathrm{~b}$ \\
\hline \multirow{4}{*}{ OER } & $1^{\text {st }}$ & $28.90 \mathrm{a}$ & $33.7 \mathrm{a}$ & $37.90 \mathrm{a}$ & $34.8 \mathrm{a}$ \\
\hline & $2^{\text {nd }}$ & $24.90 \mathrm{a}$ & $29.9 a$ & $29,07 \mathrm{a}$ & $28.3 \mathrm{a}$ \\
\hline & $3^{\text {rd }}$ & $26.30 \mathrm{a}$ & $28.8 \mathrm{a}$ & $35.10 \mathrm{a}$ & $27.4 \mathrm{a}$ \\
\hline & $4^{\text {th }}$ & $31.07 \mathrm{a}$ & - & $31.20 \mathrm{a}$ & $22.9 \mathrm{a}$ \\
\hline
\end{tabular}

${ }^{(1)}$ Means $(n=5)$ followed by equal letters in the parameters do not differ by Tukey's test, at $5 \%$ probability. ${ }^{(2)}$ Completely senescent leaves. as of the activity of photosynthetic potential (Krause \& Weis, 1991). In 'BRS Firmeza', no difference was observed in these parameters. This result reflects the presence of stay-green gene(s) in 'BRS Firmeza', which causes the persistence of leaf green color, retarding the decrease of photosynthetic light reactions and extending the assimilatory capacity of the canopy, and this fact could indicate that the PSII apparatus remains functional for longer periods in senescent leaves of the rice cultivar characterized by a stay-green phenotype, i.e. 'BRS Firmeza' is able to maintain a continued efficient energy transfer and capture in the remaining PSII apparatus.

The $\mathrm{F}_{\mathrm{V}}{ }^{\prime} / \mathrm{F}_{\mathrm{M}}{ }^{\prime}$, which expresses the effective efficiency of PSII photochemistry measured in light-adapted samples (Roháceek, 2002), did not differ in O. sativa subsp. indica BRS Pelota cultivar according to leaf position and grain-filling stage (Table 2). In contrast, $\mathrm{F}_{\mathrm{V}}{ }^{\prime} / \mathrm{F}_{\mathrm{M}}{ }^{\prime}$ was higher at the early grain-filling stage in 'BRS Firmeza' in comparison to the late stage. No differences were observed between leaves at the early grain-filling stage, but at the late stage higher values were observed in the flag and $3^{\text {rd }}$ leaves.

The earlier loss of effective photochemical efficiency should be a good indicator of senescence in 'BRS Pelota' plants, showing that the rice cultivar with higher grain-yield capacity senesces before the one with lower grain yield. Concerning the physiological significance of the senescence and its relationship with assimilate partitioning in plants, these results suggest that the higher productivity of BRS Pelota rice cultivar results from its higher assimilate mobilization ability, in spite of its lower light absorption capacity. These results are supported by the lowest chlorophyll content and by the $\mathrm{F}_{\mathrm{V}} / \mathrm{F}_{\mathrm{M}}$ values obtained in 'BRS Pelota' in both developmental stages, which showed reduction according to the leaf position (Tables 1 and 2).

In tropical $O$. sativa subsp. japonica BRS Pelota cultivar, the effective photochemical efficiency of PSII $\left(\mathrm{F}_{\mathrm{V}}{ }^{\prime} / \mathrm{F}_{\mathrm{M}}{ }^{\prime}\right)$ and the actual quantum yield of PSII electron transport in the light-adapted state $\left(\varphi_{\text {PSII }}\right)$ were not different between either grain-filling stage or leaf position (Table 2). However, in 'BRS Firmeza', $\mathrm{F}_{\mathrm{V}}{ }^{\prime} / \mathrm{F}_{\mathrm{M}}$ ' decreased with the leaf position in the late grain-filling stage. No variation was observed in $\varphi_{\mathrm{PSII}}$ and $\mathrm{F}_{\mathrm{V}}{ }^{\prime} / \mathrm{F}_{\mathrm{M}}{ }^{\prime}$ at the early grain-filling stage. The variation dynamics of photochemical quenching ( $\mathrm{qP}$ ) values was similar to that observed 
in $\varphi_{\text {PSII }}$. The photochemical quenching coefficient indicates the photon fraction absorbed by the antenna pigment used by PSII or the photochemical electron transport energy (Jiao et al., 2003). These results could indicate that BRS Firmeza rice cultivar would use the energy absorbed by PSII more efficiently and convert this energy into a photochemical effect at the late grain-development stage. Furthermore, the electron transport rate through PSII decreased from the upper to the lower leaves in both rice cultivars during both developmental stages (Table 2). The gradually decreasing changes in ETR were consistent with the changes in $\mathrm{F}_{\mathrm{V}} / \mathrm{F}_{\mathrm{M}}$ and the chlorophyll levels during plant senescence.

There were no significant differences regarding leaf position in the rates of photosynthetic oxygen evolution (OER) in both grain-filling stages of both rice cultivars (Table 2). These results were consistent with those obtained by Kura-Hotta et al. (1987), which showed that OER remained fairly constant among leaves at different positions. Also, no differences were observed in OER between the $1^{\text {st }}$ and $2^{\text {nd }}$ leaves in both IR58025a and IR58025B normal and fertility rice lines during the flowering and late grain-filling stages (Bacarin et al., 2008). However, opposite results had been observed previously in rice plants. Yamazaki et al. (1999) reported that the OER decreased with the depth of the canopy, except for the $2^{\text {nd }}$ leaves, which showed an OER similar to that of the $1^{\text {st }}$ leaves (flag leaves). That result was consistent with the increase in chlorophyll levels, which were higher in the $5^{\text {th }}$ leaves and decreased from the top to the bottom leaves. The oxygen evolution rate appears to be closely related to chlorophyll content, at least during the first week of plant development.

Although conventional plant breeding continues to produce new varieties with increased yield, the magnitude of these increases is falling, indicating that a plateau is being reached with the major yield-limiting factor being grain number (Rampino et al., 2006). The exploitation of stay-green phenotypes of the type described in the present work should potentially increase yields above this plateau through a decrease in the photosynthetic decline rate and an extension of the assimilatory capacity of the plant canopy.

\section{Conclusion}

The BRS Firmeza cultivar shows higher pigment content and higher activity of the photosynthetic apparatus in comparison to 'BRS Pelota' during the grain-filling stage.

\section{Acknowledgements}

To Conselho Nacional de Desenvolvimento Científico e Tecnológico and to Fundação de Amparo à Pesquisa do Estado do Rio Grande do Sul, for financial support.

\section{References}

ADAMS, W.W.; WINTER, K.; SCHREIBER, U.; SCHRAMEL, P. Photosynthesis and chlorophyll fluorescence characteristics in relationship to changes in pigment and element composition of leaves of Platanus occidentalis L. during autumnal leaf senescence. Plant Physiology, v.92, p.1184-1191, 1990.

ARNON, D.I. Copper enzymes in isolated chloroplasts: polyphenoloxidase in Beta vulgaris. Plant Physiology, v.24, p.1-15, 1949.

BACARIN, M.A.; FALQUETO, A.R.; COIMBRA, J.L.M.; OLIVEIRA, A.C. de; MAGALHÃES JÚNIOR, A.M. de. Oxygen evolution rate of rice cultivars. Photosynthetica, v.46, p.148-150, 2008.

BISWAS, A.K.; CHOUDHURI, M.A. Mechanism of monocarpic senescence in rice. Plant Physiology, v.65, p.340-345, 1980.

BORRÁS, L.; MADDONNI, G.A.; OTEGUI, M.E. Leaf senescence in maize hybrids: plant population, row spacing and kernel set effects. Field Crops Research, v.82, p.13-26, 2003.

CAMP, P.J.; HUBER, S.C.; BURKE, J.J.; MORELAND, D.E. Biochemical changes that occur during senescence of wheat leaves. Plant Physiology, v.70, p.1641-1646, 1982.

GENTY, B.; BRIANTAIS, J.M.; BAKER, N.R. The relationship between the quantum yield of photosynthetic electron transport and quenching of chlorophyll fluorescence. Biochimica et Biophysica Acta, v.990, p.87-92, 1989.

GOSSAUER, A.; ENGEL, N. Chlorophyll catabolism: structures, mechanisms, conversions. Journal of Photochemistry and Photobiology B: Biology, v.32, p.141-151, 1996.

HIDEMA, J.; MAKINO, A.; MAE, T.; OJIMA, K. Photosynthetic characteristics of rice leaves aged under different irradiances from full expansion through senescence. Plant Physiology, v.97, p.1287-1293, 1991 .

JIAO, D.; JI, B.H.; LI, X. Characteristics of chlorophyll fluorescence and membrane-lipid peroxidation during senescence of flag leaf in different cultivars of rice. Photosynthetica, v.41, p.33-41, 2003.

KRALL, J.P.; EDWARDS, G.E. Relationship between photosystem II activity and $\mathrm{CO}_{2}$ fixation in leaves. Physiologia Plantarum, v.86, p.180-187, 1992. 
KRAUSE, G.H.; WEIS, E. Chlorophyll fluorescence and photosynthesis: the basics. Annual Review of Plant Physiology and Plant Molecular Biology, v.42, 313-349, 1991.

KURA-HOTTA, M.; SATOH, K.; KATOH, S. Relationship between photosynthesis and chlorophyll content during leaf senescence of rice seedlings. Plant and Cell Physiology, v.28, p.1321-1329, 1987.

LICHTENTHALER, H.K. Chlorophylls and carotenoids: pigments of photosynthetic biomembranes. Methods in Enzymology, v.148, p.350-382, 1987.

LU, Q.T.; LU, C.M.; ZHANG, J.H.; KUANG, T.Y. Photosynthesis and chlorophyll $a$ fluorescence during flag leaf senescence of field-grown wheat plants. Journal of Plant Physiology, v.159, p.1173-1178, 2002.

LUQUEZ, V.M.; GUIAMÉT, J.J. Effects of the ‘stay green' genotype GGd1d1d2d2 on leaf gas exchange, dry matter accumulation and seed yield in soybean (Glycine max L. Merr.). Annals of Botany, v.87, p.313-318, 2001.

MAGALHÃES JÚNIOR, A.M. de; GOMES, A. da S.; ANDRES, A. Arroz irrigado: melhoramento genético, manejo do solo e da água e prognóstico climático. Pelotas: Embrapa Clima Temperado, 2003. p.13-33. (Embrapa Clima Temperado. Documentos, 113).

OKADA, K. Two long-term effects of light that control the stability of proteins related to photosynthesis during senescence of rice leaves. Plant and Cell Physiology, v.39, p.394-404, 1998.

RAMPINO, P.; SPANO, G.; PATALEO, S.; MITA, G.; NAPIER, J.A.; DI FONZO, N.; SHEWRY, P.R.; PERROTTA, C. Molecular analysis of a durum wheat 'stay green' mutant: expression pattern of photosynthesis-related genes. Journal of Cereal Science, v.43, p.160-168, 2006.

ROHÁĈEK, K. Chlorophyll fluorescence parameters: the definitions, photosynthetic meaning, and mutual relationships. Photosynthetica, v.40, p.13-29, 2002.
SANTOS, H.G. dos; JACOMINE, P.K.T.; ANJOS, L.H.C. dos; OLIVEIRA, V.A. de; OLIVEIRA, J.B. de; COELHO, M.R.; LUMBRERAS, J.F.; CUNHA, T.J.F. (Ed.). Sistema brasileiro de classificação de solos. 2.ed. Rio de Janeiro: Embrapa Solos, 2006. $306 \mathrm{p}$.

TANG, Y.L.; WEN, X.G.; LU, C.M. Differential changes in degradation of chlorophyll-protein complexes of photosystem I and photosystem II during flag leaf senescence of rice. Plant Physiology and Biochemistry, v.43, p.193-201, 2005.

THOMAS, H.; HOWARTH, C.J. Five ways to stay green. Journal of Experimental Botany, v.51, p.329-337, 2000.

THOMAS, H.; OUGHAM, H.J.; WAGSTAFF, C.; STEAD, A.D. Defining senescence and death. Journal of Experimental Botany, v.54, p.1127-1132, 2003.

WENG, X.Y.; XU, H.X.; JIANG, D.A. Characteristics of gas exchange, chlorophyll fluorescence and expression of key enzymes in photosynthesis during leaf senescence in rice plants. Journal of Integrative Plant Biology, v.47, p.560-566, 2005.

WIEDEMUTH, K.; MULLER, J.; KAHLAU, A.; AMME, S.; MOCK, H.P.; GRZAM, A.; HELL, R.; EGLE, K.; BESCHOW, H.; HUMBECK, K. Successive maturation and senescence of individual leaves during barley whole plant ontogeny reveals temporal and spatial regulation of photosynthetic function in conjunction with C and N metabolism. Journal of Plant Physiology, v.162, p.1226-1236, 2005.

YAMAZAKI, J.Y.; KAMIMURA, Y.; OKADA, M.; SUGIMURA, Y. Changes in photosynthetic characteristics and photosystem stoichiometries in the lower leaves in rice seedlings. Plant Science, v.148, p.155-163, 1999.

ZHANG, C.J.; CHEN, G.X.; GAO, X.X.; CHU, C.J. Photosynthetic decline in flag leaves of two field-grown spring wheat cultivars with different senescence properties. South African Journal of Botany, v.72, p.15-23, 2006.

Received on March 5, 2009 and accepted on June 31, 2009 